\title{
INVESTIMENTOS EM TRANSPORTE INTERMODAL NO BRASIL PODERIA BENEFICAR O CRESCIMENTO DO PIB
}

\author{
S. Garcia ${ }^{1,2^{*}}$, E. Vicens-Salort ${ }^{1}$, I. A. Nääs ${ }^{2}$ \\ ${ }^{1}$ UPV - Universidad Politècnica de València, CIGIP - Centro de Investigación e Gestión en \\ Ingeniería de la Producción, Espanha \\ ${ }^{2}$ UNIP - University Paulista, São Paulo, Brazil
}

\begin{abstract}
RESUMO
Brasil é um dos países em desenvolvimento que faz parte dos BRICS, os quais juntos têm um potencial de crescimento e consumo de mais de 50\% do PIB global. A distribuição de bens produzidos no território brasileiro requer um gerenciamento complexo devido a suas dimensões continentais. Uma rede de transporte mais eficiente e integrado deve reduzir os preços e trazer competitividade aos produtos brasileiros. A solução não é única e requer um planejamento global dos transportes, incluindo o uso de vários meios, transportes intermodais, o que reduzirá custos e tempo de entrega. Optou-se por um estudo qualitativo de banco de dados de agências governamentais e análise de estudos publicados sobre o tema. Este estudo apresenta os dados de custos baseado em preços internacionais. O Brasil tem adotado, tradicionalmente, o transporte rodoviário, apesar de ter outras opções disponíveis, como ferrovias ou hidrovias. Os resultados indicam que se o país não faz os investimentos necessários em modais adequados, perderá competitividade internacional levando à diminuição do PIB. Estudos de simulação de investimentos em modos de transporte e suas implicações sobre o crescimento do PIB seria o curso natural deste estudo. A importância deste trabalho é apontar para a necessidade urgente de investigar e investir outros meios de transporte nos países em desenvolvimento.
\end{abstract}

Palavras-chave: custo do transporte, redes de distribuição, simulação, caso brasileiro, transporte intermodal, transporte de grãos.

\section{INVESTMENT IN INTERMODAL TRANSPORTATION IN BRAZIL COULD BENEFIT THE COUNTRY'S AGRIBUSINESS GDP GROWTH}

\begin{abstract}
Brazil is one of developing countries part of the BRICS, which together have the potential to increase production and consumption by more than $50 \%$ of global GDP. The distribution of food produced in Brazilian territory requires a complex assessment, due to its continental dimensions. A network of more efficient and integrated transportation should reduce prices and bring competitiveness to Brazilian products. The solution is not unique and requires a global transportation planning, including using various means, intermodal transportation, to reduce costs and delivery time. This study aimed to analyze alternative modals other than roads, to deliver products within Brazilian territory. A database qualitative study was selected using governmental agencies data and analysis of published studies on the topic. Simulation was done to bring the decision-making using officials data projection. Using data from the literature review of government data on the subject, and further application in transport, simulation was applied seeking other alternatives for roads. Results presented national options and their costs based on international prices. Brazil has traditionally adopted


road transportation, and other options are available, as railways or waterways. Results also indicate that if the country does not make the necessary investments in adequate modals, it will lose international competitiveness leading to decrease in the GDP. Include simulation studies on investments in modes of transport and its implications on GDP growth would be the natural course of this study. The importance of this study is to point out the urgent need to investigate and invest other means of transport in developing countries.

Keywords: cost of transport, distribution networks, simulation, intermodal transport, railroad, transportation of grains.

\section{INTRODUCTION}

Brazil has vast geographical proportions, and the costs for handling and movement of materials and products are high over long distances. These increases the final cost, and consequently the price of the final product. This scenario continues to bring investment losses, and the decline in the quality of the Brazilian modal transport infrastructure, increases the loss of international competitiveness. Worldwide, Brazil stands in the 48th position, in transportation infrastructure, among 144 countries, and in the 65th place in logistics (WORLD ECONOMICS, 2012; CALEIRO, 2014). It is recognized that the growing use of intermodal transport can be a stopgap solution while real solutions are not enough (FARIA \& COSTA, 2010). Business decision should take in a systemic and integrated form of logistics operations. These decisions involve a complex network of relationships with various levels of the chain business, and were related to production, procurement, storage and replacement policies, material handling and physical distribution (CHOPRA \& MEINDL, 2010; BALLOU, 2011). According to FARIA \& COSTA (2010) particular service levels and logistic decisions in business in the supply chain may cause significant impacts on business competitiveness. In the other hand, the total costs cannot compromise the quality of value aggregation to the customer and does not to prejudice the return for their investors. A research was carried out by REXHAUSEN et al. (2012) points out that to manage the logistics within the supply chain concept has gained much importance in recent years. The authors show to the customer what the company may offer to the client - services and products. According to the authors, demand management has emerged as a new dimension of the interface, as the impact on suppliers and customers, and has been analyzed in an interdisciplinary manner. That does not occur in academic research and daily basis business. Brazilian transportation is made by roads, highways, railroads, seaport, river ports, and ducts. Road transportation is by far the most common way of circulating goods in the country. Despite the government emphasizes investments in this segment, roads are not a high priority for the country. It is a challenge to find a proper way of circulating goods in an integrated way. The maritime transportation is usually done in an open sea, and it depends on seaport infrastructure. Brazil has potential waterways as rivers flow all over the country; however, from the $43,000 \mathrm{~km}$ of navigable waterways only $10,000 \mathrm{~km}$ are used, which account for $13 \%$ of cargo BRASIL (2013). For coastal shipping, there are 42 Brazilian Shipping Companies (EBNs) authorized to operate a fleet of 155 ships and to total three million deadweight tons per year (TPB) (BALLOU, 2011). Goods with a small benefit and in large volumes (agricultural products, fertilizers, coal, and oil) are transported by railroads, which are obsolete. The transport via pipelines is used for large volumes of oil, fuel oil, gasoline, diesel, ethanol, LPG, kerosene and naphtha, and for natural gas (BRASIL, 2013). The transport system using pipelines has been used since 2009, and it totalizes $22,000 \mathrm{~km}$ consisting of 
569 pipelines (ABRATEC, 2012; CNT, 2012c). They belong to private companies. Worldwide, Brazil, is the $16 \mathrm{t}^{\mathrm{h}}$ country moving 33,300 RTK (tons transported per $\mathrm{km}$ ), or $4.2 \%$ of total transported (CNT, 2012a). This modal provides lowest rates and better security than other transportation methods. In terms of air freight, Brazil is one of the five largest in the world, has 742 public airports and 150 million people were transported in 2010. There were 300 aircraft scheduled airlines in 2012, and it is the $3^{\text {rd }}$ largest aerospace industry - EMBRAER (IATA, 2013).

Complex management problems can have solutions approach by strategic thinking through simulations (LANE, 1995). Mathematical simulation also may help entrepreneurs in their logistics decisions, costing and performance indicators without using real money, with less risk to the business. Prior knowledge of the values might be used as input for the supply, production, and distribution, which becomes a sustainable competitive advantage for the company, with total control of costs (LEAN et al., 2006). This solution is useful to approach decision-

\section{METHODOLOGY}

One of the difficulties the country is how to make the products arrive quickly at their outlets from imports, which usually comes from the ports or airports. Thus, the products distributed when arrive in Brazil by train, ship or coastal line. Simulation was done to bring the decision-making using officials data projection. Using data from the literature review of government data on the subject, and further applica-tion in transport, simulation was applied seeking other alternatives for roads. Decision on the investments in transportation was searched in the governmental sites, and used in the evaluation. making in complex and dynamic process environments, increasing and improving their experience in the field, with less financial risk than usually (YARSACAN, 2010). For researchers, the model of computer simulation offers several significant advantages (KELTON et al., 2004) as it allows investigating events that could be potentially disastrous for most companies. Moreover, it helps to review and understand processes that would take much time to complete, and could bring influences of external factors, including human intervention. Methods of mathematical optimization models, and simulation are sueful tools in the process of Business Administration. Such tools may provide ways to plan the supply chain and business support decisions, besides warning about of the uncertainties in supply and demand also are (ACAR et al., 2010).

This study aimed to analyze investments in Brazil and BRIC food transportation infrastructure and their influence on GDP growth in these countries.

IPEA (2013) and UNITED NATIONS (2014) present a projection of investment until 2016 to transportation modes and their mean for GDP growth from these investments. Far from ideal, this suggestion is an initiative that the government should take based on next investments. It was also observed that manufacture products are generally transported by expensive modal (road and airfreight).

The final step was to analyze if the investment in freight transportation by modes (other than highways and roads) can ensure international competitiveness and better internal distribution, as well as the drop in prices of Brazilian products. 


\section{RESULTS AND DISCUSSION}

According to PENA (2013), the acronym BRIC countries was defined by the economist Jim O'Neill, ad it represents emerging economies with substantial investment capacity that became economic powers in 2050 - Brazil, Russia, India, and China. The letter $\mathrm{S}$ was added at the end of the acronym in 2006 (BRICS), when South Africa joined the group. These countries together account for over $40 \%$ of the world population, have growth rates and successive improvements in per capita income, GDP (Gross Domestic Product) and the Human Development Index (HDI). The BRICS are responsible for growth of about $55 \%$ of the global economy scenario in developed countries contributed only $20 \%$. The Brazilian grain harvest for the period 2013/2014 is estimated at around 200 tons (BRASIL, 2015). However, this development in Brazil was not accompanied by essential investments in transportation infrastructure. A total of 500 million tons of goods circulated in seaports, in 2009, about 100 million tons of imports and 400 million tons in exports (BRASIL, 2013). Estimates show that, by 2030, one-third of the products sold in the world come from BRASIL (2011). Trade and transport via waterways, railways, pipelines, and seaports begin to add value to the product, according to projections made by the Brazilian Association of Container Terminals for Public Use (ABRATEC, 2013), a container handling in Brazil will double by 2021. Currently, products made in Brazil represent a turnover of about $5 \%$ of total world exports (BRASIL, 2013a; ABRATEC, 2013).

Despite the apparent differences and advantages in other modes, Brazil prioritizes transporting cargo by road. This issue contradicts the new world global order and the search for innovation, sustainability, competitiveness and reduction in costs. Figure 1 shows that $61.1 \%$ of Brazilian cargo is transported by road, using gasoline and diesel, nonrenewable fuels. With high costs, it should only be used to transport high-value merchandises or perishable, finished or semi-finished goods. Despite being the most transportation employed in Brazil, its disadvantages in relation to other modes are bringing some change in their share of the transportation matrix (BRASIL, 2009; 2013). Most companies are private business; however, the major construction of road transportation infrastructure is still the government. Consortia companies have controlled by railroads (BRASIL, 2009).

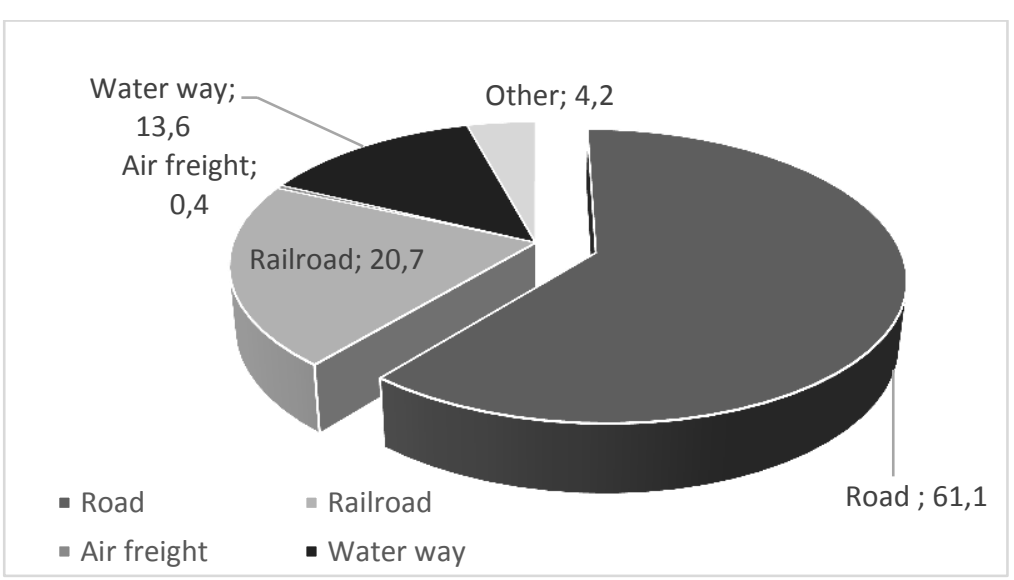

FIGURE 1- Freight transportation forms in Brazil (Adapted from CNT, 2012b).

The mere adoption of containers in maritime and waterway transportation according to ABRATEC (2013), lead to faster shipments and reduce labor cost. This trend to increase the volumes transported in a million TEUs (Twenty 
Feet Equivalent Unit or - drive twenty feet or equivalent) per year. ABRATEC affiliated companies intend to invest US\$ 10.5 billion in expansion by 2021 . Through 2016 , there will a use of US $\$ 4.5$ billion in construction of vessels and expanding the physical space for the containers. Waterways allow the movement of large amounts of goods over long distances of major commodities minerals, gravel, sand, coal, iron ore, grain and other nonperishables (ABRATEC, 2013).

A study of the major logistical difficulties and export in Brazil shows that it disrupts the market, and it increases the costs. The choice of modes to WANKE \& HIJJAR, 2009) is directly associated to cost. Historically, Brazilian government invested more in highway than in other modes, contrariwise to what makes the US, which in 2008 carried only $28 \%$ of their cargo by road. Meanwhile in Brazil, $62 \%$ of goods are transported by roads. The realities of the two countries are different compared to the existing transport infrastructure. Although the data is from 2008, the proportion of use of transport has remained WANKE \& HIJJAR, 2009). In poor countries, the lack of roads constitutes an obstacle to development (UNITED NATIONS, 2009). Therefore, public investment in transportation infrastructure represents yet a small fraction of the GDP. South Africa does not have this information (Table 1).

TABLE 1. Comparison of investments in public transportation in BRICS countries

\begin{tabular}{llll}
\hline \multicolumn{3}{c}{ Results in transportation in the BRIC countries (2010) } \\
\hline Country & $\begin{array}{l}\text { PIB } \\
10^{9} \text { US\$ }\end{array}$ & $\begin{array}{l}\text { Public investment in } \\
\text { transportation infra- } \\
\text { structure } \\
\left(10^{9} \text { US } \$\right)\end{array}$ & $\begin{array}{l}\text { Public investment } \\
\text { infra- } \\
\text { structure/GDP, } \%\end{array}$ \\
\hline Brazil & 2.17 & 7.81 & $0.36 \% *$ \\
Russia & 2.22 & 155.40 & $7.00 \%$ \\
India & 4.06 & 324.80 & $8.00 \%$ \\
China & 10.09 & 1.015 .05 & $10.06 \%$ \\
\hline
\end{tabular}

*When considering private investments the total in transportation infra-structure represents $0.56 \%$ of the GDP. Source: (BRAZIL, 2011; IPEA, 2013)

Government investments in infrastructure have fallen in recent decades. In 1975, it represented $1.84 \%$ of GDP; in 1987, $0.82 \%$, and in the 90s, the investment never exceeded $0.5 \%$ of GDP. From the 2000s, they began to show a slight upward trend (CNT, 2012b). Modal transport, and investments when applied accurately indicate that the money will triple in the railroad investment until 2016 (over the past three years). The figure is equivalent to $R \$ 27$ billion in the period 2008-2011, to $\mathrm{R} \$ 77$ billion in the period 2013 - 2016 (Figure 2).

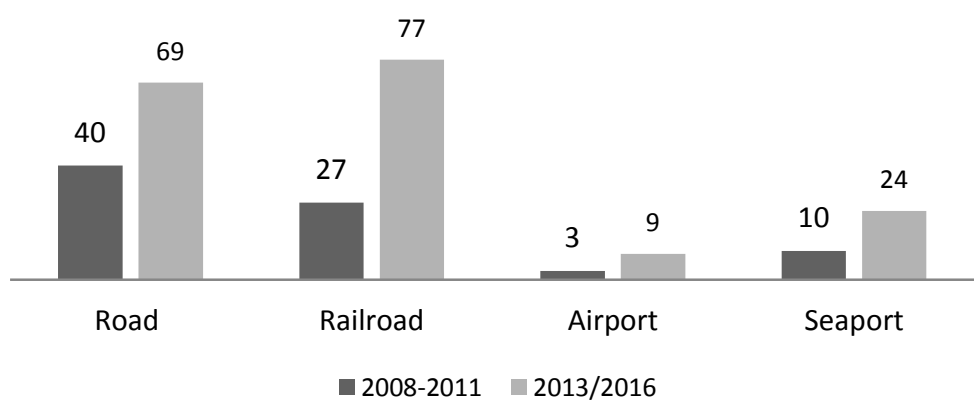

FIGURE 2 - Brazilian governmental investments in transportation in the years 2008-2011, and the forecast for the years 2013-2016. 
Data from IPEA (2013) suggests that the Brazilian government needs to invest in the modal infrastructure in the next 15 years. Due to the unbalanced logistic matrix by the over-involvement of road transport, the cost of transport has decreased competitiveness of Brazilian goods. The study suggests that the public and private resources are around $3.4 \%$ of GDP in the first five years of the new model and $2 \%$ of GDP over the next decade. Table 2 details the program, comparing the values proposed by modal analysis with inversions between 2006 and 2010.

TABLE 2- Projection of the investment required in transportation infrastructure in Brazil

\begin{tabular}{llll}
\hline Modal & $\begin{array}{l}\text { Investment } \\
\text { required } \\
\text { Year } 1-5-10^{9} \\
\text { R } \$ \text { /year }\end{array}$ & $\begin{array}{c}\text { Investment } \\
\text { required } \\
\text { Year } 1-5 \\
\% \text { PIB }\end{array}$ & $\begin{array}{l}\text { Investment required } \\
\text { Year 6-10 - } 10^{9} \\
\text { R \$ /year }\end{array}$ \\
\hline Road & 69.03 & 1.88 & 28.4 \\
Railroad & 29.83 & 0.81 & 29.6 \\
Port & 17.46 & 0.48 & 10.9 \\
Air freight & 8.63 & 0.23 & 4.7 \\
\hline \multicolumn{1}{c}{ Total } & 124.95 & 3.40 & 73.6 \\
\hline & Source: IPEA (2013); UNITED NATION (2014).
\end{tabular}

Table 3 shows a simulation of international freight fees REBELO (2011), presenting the damage suffered by the country with the mistaken choices of investment in transport modes. Average cost difference between Brazil and US hits US\$ 20 billion (considering conversion rate US $\$ 1.00=\mathrm{R} \$ 3.00)$. FARIAS et al. (2015) confirms REBELO's (2011) study. Another government investment should be in establishing appropriate fixed points of origin and destination, generating economic efficiency and greater share of transportation of internal and external loads within the country. This would promote fixed costs from initial investments, and it facilitates the flow of agricultural products, minerals, and energy, which are sectors that still have substantial logistical barriers.

TABLE 3 - Average cost of transportation in Brazil and the US.

\section{Load transported Matrix of transportation (\%) Mean freight- \\ International}

standard

Modal

\begin{tabular}{|c|c|c|c|c|c|c|c|}
\hline \multirow{4}{*}{ a } & \multirow{4}{*}{$10^{6} \mathrm{TKU}$} & \multirow{4}{*}{$10^{3} \mathrm{TU}$} & \multirow{2}{*}{\multicolumn{2}{|c|}{ Brazil }} & \\
\hline & & & & & EUA & Brazil & EUA \\
\hline & & & With & Without & & & \\
\hline & & & Iron & Iron & & & \\
\hline Road & 488.000 & 456.000 & 60 & 70 & 26 & 45.0 & 56,0 \\
\hline Railroad & 188.000 & 356.000 & 22 & 9 & 34 & 18.0 & 14,0 \\
\hline Waterway & 112.000 & 398.000 & 14 & 17 & 25 & 12.0 & 5,0 \\
\hline Duct & 24.000 & 24.000 & 3 & 3 & 14 & 10.0 & 10,0 \\
\hline Airfreight & 8.000 & 8.000 & 1 & 1 & 1 & 360.0 & 320,0 \\
\hline Total & 820.000 & 1.266 .000 & 100 & 100 & 100 & & \\
\hline \multicolumn{3}{|c|}{ Mean cost - US $\$ / 10^{3}$ TKU } & 36.0 & 39.0 & 25.0 & & \\
\hline
\end{tabular}




\section{FINAL REMARKS}

Brazil, with the role of developing country, should redesign the transportation infrastructure for their products to improve internal and external competitiveness. Joining the transportation network in all kinds of modals is a challenge for all countries.

In Brazil, although there are few resources in most modes, further integration could already yield better results for companies, either in speed, or in lower prices than usual. Priority should focus on infrastructure expansion integrating Brazilian cargo transport matrix, whose main goal would be to prioritize the development of the railroad and waterway to expand the system capacity.

\section{ACKNOWLEDGEMENT}

The authors wish to thank CAPES and CNPQ, and the Universitat Politècnica de València (UPV).

\section{REFERENCES}

ABRATEC. Associação Brasileira dos Terminais de Contêineres de Uso Público. Estatísticas. 2015. Available at: http://www.abratec-

terminais.org.br/estatisticas. Accessed on: February 2015.

ABRATEC. Associação Brasileira dos Terminais de Contêineres de Uso Público (Abratec) e Câmara Brasileira de Contêineres, Transporte ferroviário e Multimodal (CBC). ANTT. Agência Nacional de Transportes Terrestres. Portos 2021. Parceria com Instituto de Logística e Supply Chain (ILOS). Available at: http://www.sevensolucoes.com.br/clientes/ abratec2/files/Portos2021_Avaliacao_de_ Demanda_e_Capacidade_do_Segmento_P ortuario_de_Conteineres_no_Brasil.pdf. Accessed on: March 2015. 2012.

ACAR, Y.; KADIPASAOGLU, S.; SCHIPPERRIJN, P. A.; Decision support for global supply chain modeling: an assessment of the impact of demand, supply and lead-time uncertainties on performance. International Journal of Production Research, v. 48(11): 32453268, 2010.

BALLOU, R. H. Gerenciamento da Cadeia de Suprimentos/Logística Empresarial. Porto Alegre: Bookman, 2011.

BRASIL. ANTT. Associação Nacional dos Transportes Terrestres. Transportation data
2008-2009. Available at: http:// http://www.transportes.gov.br/transporteferroviario.html. Accessed on: February 2015, 2009.

BRASIL. Ministério da Agricultura, Pecuária e Abastecimento. Agrostat. Estatísticas de Comércio Exterior do Agronegócio Brasileiro. Available at: http://www.brasilexport.gov.br/estatisticasbrasil-0. Accessed in April 2014, 2011.

BRASIL. Ministério dos Transportes. Linhas de Cabotagem. Available at: http://www2.transportes.gov.br/bit/05mar/cabotagem.html. Viewed in: February 2015, 2013.

BRASIL. Ministério dos Transportes. Transportes Marítimos. Available at: http://www2.transportes.gov.br/bit/04hidro/hidro.html. Accessed on: February 2014, 2013a.

BRASIL. Conab. Produção de grãos pode ultrapassar 196 milhões de toneladas. Portal Brasil. Available at: http://www.BRAZIL.gov.br/economia-eemprego/2013/11/o-ibge-preve-safra-degraos-1-4-menor-em-2014. Accessed on: February 2015, 2015.

CALEIRO, J. P. 15 países com melhor logística no mundo (e o BRAZIL em $65^{\circ}$ ). Exame. Available at: http://exame.abril.com.br/economia/noticia s/15-paises-com-melhor-logistica-no- 
mundo-e-o-BRAZIL-em-65o. Accessed on: March 2014, 2014.

CHOPRA, S.; MEINDL, P.; Gestão da Cadeia de Suprimentos: estratégia, planejamento e operações. São Paulo: Pearson Prentice Hall (2010).

CNT. Confederação Nacional dos Transportes. 2012. Pesquisa CNT de Ferrovias 2011. Brasília: CNT (2012a).

CNT. Confederação Nacional dos Transportes. 2012. Pesquisa CNT de Rodovias 2012. Brasília: CNT (2012b).

CNT. Confederação Nacional do Transporte. O Transporte Dutoviário. Economia em Foco. 28.08.2012. Available at:

http://www.cnt.org.br/Imagens\%20CNT/P DFs\%20CNT/Economia\%20em\%20foco/E CONOMIA_EM_FOCO_28_de_agosto_2 012.pdf. Accessed on: April 2014, $2012 c$.

FARIA A. C.; COSTA, M. F. G. Gestão de Custos Logísticos. São Paulo: Atlas, 2010.

FARIAS, A. B G. de; FERREIRA, T.; RODRIGUES, M. V.; NUNES, F. R. PERSPECTIVAS DO CUSTO LOGÍSTICO NO BRASIL E COMPARAÇÃO COM O CASO NORTEAMERICANO. OTOC. Ordem dos Técnicos Oficiais de Contas. Available at: http://www.otoc.pt/news/PENCUSTOS/pd f/146.pdf. Accessed on: February 2015.

IATA. International Air Transport Association. Dados gerais sobre transportes aéreos. Available at: www.iata.org. Viewed: April 2014, 2013.

IPEA. Instituto de Pesquisa Econômica Aplicada. Oportunidades e desafios para a engenharia consultiva no Brasil. GARCIA, J. L. K. (Conselho do Programa Diagnóstico, Perspectivas e Alternativas para o Desenvolvimento do Brasil junto com o Banco Interamericano de Desenvolvimento, 2013.

KELTON, W. D; SADOWSKI, R. P.; STURROCK, D. T. Simulation with Arena. New York: McGraw-Hill, 2004.

LANE, D. C. On the Resurgence of Management Simulation and Game.
Journal of the Operational Research Society, 46(5): 604-25, 1995.

LEAN, J.; MOIZER, J.; TOWLER, M.; Abbey C. Simulations and games - Use and barriers in higher education. Active Learning in Higher Education, 7(3): 227242, 2006.

PENA, R. F. A. BRICS. Acordos Internacionais. Available at: www.mundoeducacao.com/geografia/bric. htm. Accessed on: April 2014, 2013.

REBELO, J. Logística de Carga no Brasil: Como reduzir Custos Logísticos e Melhorar Eficiência? The World Bank. Sustainable Development Department. Sustainable Development Department. Latin America and Caribbean Region. Dec 2011. Available at: http://siteresources.worldbank.org/BRAZI LINPOREXTN/Resources/38171661323121030855/JorgeRebelo.pdf?resource urlname=JorgeRebelo.pdf. Accessed on: February 2015, 2011.

REXHAUSEN, D.; PIBERNIK, R.; KAISER, G. Customer-facing supply chain practices - The impact of demand and distribution management on supply chain success. Journal of Operations Management, v. (30): 269-281, 2012.

UNITED NATIONS. Banco Mundial. Best Practices in Investment for Development. Investment Advisory Series. S. B, n. 2. Lessons from Australia and Peru. New York and Geneva, 2009.

UNITED NATIONS. Banco Mundial. Best Practices in Investment for Development. Investment Advisory Series. Ed. 2014, 2014.

WANKE, P. F.; HIJJAR, M. F. Exportadores brasileiros: estudo exploratório das percepções sobre a qualidade da infraestrutura logística. Produção, v. 19(1): 143-162, 2009.

WORLD ECONOMIC FORUM. The global competitiveness report 2012 - 2013. Geneva: World Economic Forum, 2012. Available at: http://www3.weforum.org/docs/WEF_Glo 
balCompetitivenessReport_2012-13.pdf.

Accessed on: February 2015.

YARSACAN, H. Improving

Understanding, Learning, and

Performances of Novices in Dynamic

Managerial Simulation Games.

Complexity, v.15(4): 31-42, 2010. 